\title{
Flame atomic absorption spectrometric determination of heavy metals in aqueous solution and surface water preceded by co-precipitation procedure with copper(II) 8-hydroxyquinoline
}

\author{
Ayodele Rotimi Ipeaiyeda $^{1}$ - Abisayo Ruth Ayoade $^{1}$
}

Received: 15 June 2017/ Accepted: 11 July 2017/Published online: 17 July 2017

(c) The Author(s) 2017. This article is an open access publication

\begin{abstract}
Co-precipitation procedure has widely been employed for preconcentration and separation of metal ions from the matrices of environmental samples. This is simply due to its simplicity, low consumption of separating solvent and short duration for analysis. Various organic ligands have been used for this purpose. However, there is dearth of information on the application of 8-hydroxyquinoline (8-HQ) as ligand and $\mathrm{Cu}$ (II) as carrier element. The use of $\mathrm{Cu}$ (II) is desirable because there is no contamination and background adsorption interference. Therefore, the objective of this study was to use 8-HQ in the presence of $\mathrm{Cu}$ (II) for coprecipitation of $\mathrm{Cd}(\mathrm{II}), \mathrm{Co}(\mathrm{II}), \mathrm{Cr}(\mathrm{III}), \mathrm{Ni}(\mathrm{II})$ and $\mathrm{Pb}$ (II) from standard solutions and surface water prior to their determinations by flame atomic absorption spectrometry (FAAS). The effects of $\mathrm{pH}$, sample volume, amount of 8-HQ and $\mathrm{Cu}$ (II) and interfering ions on the recoveries of metal ions from standard solutions were monitored using FAAS. The water samples were treated with 8-HQ under the optimum experimental conditions and metal concentrations were determined by FAAS. The metal concentrations in water samples not treated with 8-HQ were also determined. The optimum recovery values for metal ions were higher than $85.0 \%$. The concentrations $(\mathrm{mg} / \mathrm{L})$ of $\mathrm{Co}(\mathrm{II}), \mathrm{Ni}(\mathrm{II}), \mathrm{Cr}(\mathrm{III})$, and $\mathrm{Pb}(\mathrm{II})$ in water samples treated with 8 -HQ were $0.014 \pm 0.002,0.03 \pm 0.01$, $0.04 \pm 0.02$ and $0.05 \pm 0.02$, respectively. These concentrations and those obtained without coprecipitation technique were significantly different. Coprecipitation procedure using $8-\mathrm{HQ}$ as ligand and $\mathrm{Cu}(\mathrm{II})$ as carrier
\end{abstract}

Ayodele Rotimi Ipeaiyeda ayosade2003@yahoo.com

1 Department of Chemistry, University of Ibadan, Ibadan, Nigeria element enhanced the preconcentration and separation of metal ions from the matrix of water sample.

Keywords Co-precipitation · 8-hydroxyquinoline · Surface water - Heavy metals - Atomic absorption spectrometry

\section{Introduction}

Heavy metals are toxic elements that can result from pollution of surface water. Their presence could pose risks and hazard to human and their trace levels in the environment are regulated by various laws prescribed by various authorities in each country. The levels of heavy metals found in the environment should be generally lower than the levels stated by the regulatory laws (Ákesson et al. 2006). Heavy metals are naturally found in the environment but their levels in the environment increase due to various anthropogenic activities from industries, mining and smelting, emissions from vehicles, fertilizers, old water supply infrastructure, contaminated paints, lead-acid batteries, treated woods and micro plastics floating in the biosphere's oceans (Harvey et al. 2015). Due to the incessant environmental problems of heavy metal pollution, various methods are arising to accurately determine the concentrations of metal ions in environmental samples. The techniques that have found relevance in the application of analytical chemistry for the determination of trace heavy metals are Graphite Furnace Atomic Absorption Spectrometry (GFAAS), Inductively Coupled Plasma-Atomic Emission Spectrometry (ICP-AES) and Flame Atomic Absorption Spectrometry (FAAS) (Burham 2009). For this study, FAAS was used to determine heavy metals because of its low cost and easy usage. The commonly used 
separation enrichment techniques for trace heavy metals from environmental samples are adsorption, solvent extraction, cloud point extraction membrane filtration (Çelik et al. 2010; Marahel et al. 2011; Soylak 2004; Soylak et al. 2005) The use of large volume of appropriate solvents and non-ionic surfactants limits the application of these techniques in analysis of environmental samples. The use of separation and preconcentration procedure for the determination of trace heavy metals prior to FAAS application is very important because analysis is achieved at lower level of detection limit than when the procedure in not applied. Also, the interference effects of the foreign ions in the samples are minimal when separation-preconcentration procedure is applied (Tokman et al. 2004; Yang et al. 2004).

Co-precipitation method is one of the effective techniques for the determination of trace heavy metal ions among the separation-preconcentration-separation techniques (Duan et al. 2003). Co-precipitation technique usually involves carrying down by the precipitate of desired elements with a carrier element (a substance that has similar crystalline structure and that can aid the incorporation of the desired element from the sample matrix into solution) especially if the trace elements to be determined is too dilute and cannot be precipitated by any conventional means (Tchounwou et al. 2012). The technique is effective in that it is fast, simple, and numerous analyte ions can be preconcentrated and separated from the matrix concurrently. Organic and inorganic co-precipitants have been reported for co-precipitation of heavy metal ions at trace levels from environmental samples (Elci et al. 2003). Inorganic ligands reported as co-precipitants in literatures were hydroxide, thiocyanate, phosphates and organic ligands were dibenzyldithiocarbamate, N-benzoylN-phenyl-hydroxylamine, 2-nitroso-1-napththol-4 sulfonic acid (Chen et al. 1997; Depecker et al. 2009; Tuzen and Soylak 2009; Uluozlu et al. 2010; Vircavs et al. 1994; Zhang et al. 2010).

8-Hydroxyquinoline has been identified as a non-vinylated ligand which cannot bond chemically to the polymer chains, but can be trapped inside the polymeric matrices. The use of non-vinylated 8-hydroxyquinoline in polymeric form has been successfully applied for co-precipitation of certain metal ions following the trapping technique. By using the trapping technique, a synthesized nickel ionic imprinted polymer (IIP) containing 8-hydroxyquinoline ligand showed affinity for $\mathrm{Cu}(\mathrm{II}), \mathrm{Pb}$ (II) and $\mathrm{Cd}(\mathrm{II})$ from their standard solutions and seawater. When these solutions passed through an alkaline conditioned IIP cartridge, preconcentration factors of 40 and 100 were, respectively, achieved for 100 and $250 \mathrm{~mL}$ each of the solutions under the operating conditions. These metal ions were quantitatively retained $(>80 \%)$ in the IIP solid phase within $\mathrm{pH}$ of
8.0 and 9.0 (Otero-Romaní et al. 2009). These optimum pH values at which the metal ions were retained by IIP were similar to the optimum $\mathrm{pH}$ range of $8-9$ obtained in this study.

The selectivity of 8-hydroxyquinoline (8-HQ) for metal ions can be enhanced if combined with $\mathrm{Fe}_{2} \mathrm{O}_{3}$ and anchored on chitosan using epichlorohydrin as a crosslinking agent. A bio-based 8-HQ anchored magnetic chitosan using $\mathrm{Co}(\mathrm{II})$ as imprinted ions and epichlorohydrin as crosslinking agent has successfully been applied for selective removal of cobalt ion relative to nickel and lead ions from water and food samples (Beyki et al. 2016). This procedure can offer the advantage of highly effective separation of metal ions in magnetic field. However, it is expensive compared to the proposed coprecipitation procedure in this study for which magnetic nanoparticles and chitosan are not in use. The use of chelating agent with carrier element alone in coprecipitation technique is much more convenient, inexpensive and can readily be adopted in the preconcentration of metal ions (Y1ldiz et al. 2016). 8-HQ was identified as the main functional group in the composite structure, which played an important role in cobalt ion removal from solution (Beyki et al. 2016). Therefore, the objective of this study was to determine the concentrations of some heavy metal ions in Lagos lagoon water using co-precipitation procedure involving 8-hydroxyquinoline and $\mathrm{Cu}(\mathrm{II})$ solution as precipitating agent and carrier element, respectively. The metal concentrations of water sample treated with 8-hydoxyquinoline was subsequently employed to evaluate the metal pollution load of the lagoon water. To assess the accuracy of the method, a certified reference sediment material was analyzed for heavy metals following co-precipitation procedure since reference material for water was unavailable to use.

\section{Materials and methods}

A Perkin-Elmer Model analyst 200 Atomic Absorption Spectrophotometer equipped with single element hollow cathode lamp and $10 \mathrm{~cm}$ air-acetylene burner was used for the determination of the metals ions. A pH meter, HANNA $\mathrm{pH}-211$ digital glass electrode, was used to measure $\mathrm{pH}$ values. MSE Mistral 2000 model centrifuge was employed for centrifugation of solutions. Chemicals used in this study were of analar grade and further purification was not required. Standard stock solutions containing $1000 \mu \mathrm{g} / \mathrm{mL}$ of nitrate salts of $\mathrm{Pb}(\mathrm{II}), \mathrm{Cr}(\mathrm{III}), \mathrm{Co}(\mathrm{II}), \mathrm{Ni}(\mathrm{II})$ and sulfate of $\mathrm{Cd}$ (II) were prepared in $1 \mathrm{~L}$ volumetric flasks and made up to the mark with distilled deionized water. A solution of 8-hydroxyquinoline $(0.1 \%, \mathrm{w} / \mathrm{v})$ was prepared by dissolving $0.1 \mathrm{~g}$ of the salt in ethanol and then diluting to the mark with ethanol in $100 \mathrm{~mL}$ volumetric flask. A solution of 
$\mathrm{Cu}(\mathrm{II})$ solution $(1000 \mu \mathrm{g} / \mathrm{mL})$ was prepared by dissolving $2.5 \mathrm{~g}$ of $\mathrm{CuSO}_{4}$ quantitatively into a little distilled water contained in $1 \mathrm{~L}$ volumetric flask and made up to the mark with distilled water. The $\mathrm{pH}$ of the standard solution was adjusted with $0.1 \mathrm{M} \mathrm{HCl}$ and $0.1 \mathrm{M} \mathrm{NaOH}$ solutions.

\section{General procedure for method development using a model solution}

The co-precipitation method for the use of 8-hydroxylquinoline and $\mathrm{Cu}(\mathrm{II})$ was tested with various model solutions of lead, cobalt, cadmium, chromium and nickel before applying them to water samples. Solutions containing $20 \mu \mathrm{g}$ each of aqueous solutions of $\mathrm{Pb}$ (II), $\mathrm{Ni}$ (II), $\mathrm{Co}(\mathrm{II}), \mathrm{Cr}(\mathrm{III})$, and $\mathrm{Cd}(\mathrm{II})$ were placed into different centrifuge tubes. This was followed by the addition of $2 \mathrm{mg}$ of $5 \%(\mathrm{w} / \mathrm{v})$ of 8-hydroxyquinoline and $0.2 \mathrm{mg}$ of $\mathrm{Cu}^{2+}$ as carrier element. The $\mathrm{pH}$ of the solutions in the different tubes was adjusted to $\mathrm{pH}$ of $3-10$ by adding drops of $\mathrm{HNO}_{3}$ or $\mathrm{NaOH}$ appropriately.

The solutions were left to stand for $10 \mathrm{~min}$ and then centrifuged at $3500 \mathrm{rpm}$ for $20 \mathrm{~min}$. The supernatant was decanted and the precipitate formed was dissolved in $1 \mathrm{~mL}$ concentrated nitric acid. The solution was transferred into a $10 \mathrm{~mL}$ volumetric flask and made up to mark with deionized water. The concentrations of the heavy metals in the aqueous solutions were then determined using Flame Atomic Absorption Spectroscopy (FAAS).

\section{Description of sampling area}

The Lagos lagoon is a reservoir of last resort for over $70 \%$ of the surface runoffs, drainage channels and important rivers flowing from Nigeria to the Atlantic Ocean (Hill and Webb 1958; Okusipe 2003). The Lagos city harbors over $75 \%$ of the industrial outfits within the country. These include metal, shipyards, breweries and bottling companies, textile, paint, chemical, plastic and petrochemical factories, paper mills and sawmill industries. Also included are side recreational and tourist centers built around the lagoon at several location in the city. The high amount of waste generated daily in the city is as a result of the large population and the nature of industries in the area (Ajao 1990). These industries discharge untreated wastes into several drainages and canals that litter the metropolis. The wastes eventually get into the Lagos Lagoon. Residents living around the lagoon also actively dump solid wastes into the lagoon, thereby adding to the pollution. The Lagos lagoon is the largest of the three lagoon systems existing in the Lagos city, and it receives over $80 \%$ of the land derived run-offs laden with various types of wastes. The lagoon receives the discharge of the Ogun River (Marchand et al. 2006) and empties into the Atlantic via Lagos Harbour, a main channel through the heart of the city (Fig. 1). The lagoon is more than $50 \mathrm{~km}$ long and $3-13 \mathrm{~km}$ wide, separated from the Atlantic Ocean by long sand spit of $2-5 \mathrm{~km}$ wide, which has swampy margins on the lagoon side. Its surface area is approximately $6354.7 \mathrm{~km}^{2}$ (Pekey 2006). The depth of the lagoon ranges from 3 to $10 \mathrm{~m}$, which makes it fairly shallow and plied by only smaller barges and boats (Rainey et al. 2003). This activity can contribute to heavy metals enrichment of water bodies (Abdel-Satar and Geneid 2009; Awoyemi et al. 2014).

\section{Preservation and preparation of water samples}

Five water samples were collected in $1 \mathrm{~L}$ plastic bottles from different locations at about $200 \mathrm{~m}$ away from each sampling point. The sampling was carried out weekly for 3 months. The sample containers were pre-washed in acid solution and rinsed with distilled water twice to ensure minimal interference. The water sample was preserved with $2 \mathrm{~mL}$ of concentrated nitric acid after collection, kept in an ice chest in the field and later stored in the refrigerator at $4{ }^{\circ} \mathrm{C}$. The acidified water samples was neutralized and adjusted to a $\mathrm{pH}$ of 7 . The water samples were treated with concentrated nitric acid following standard procedures of the American Public Health Association, filtered with 0.45 micron filters into $10 \mathrm{~mL}$ volumetric flasks and made up to the mark with deionized water (APHA-AWWA-WPCF 1981). The concentrations of heavy metals in the filtrates were determined by flame atomic absorption spectrometry (FAAS).

\section{Application of co-precipitation procedure to water sample}

A $10 \mathrm{~mL}$ of water sample was accurately measured into a beaker and $1 \mathrm{~mL}$ of concentrated nitric acid was added to it. This was concentrated on a water bath for few minutes in the beaker, filtered into a $10 \mathrm{~mL}$ volumetric flask and made up to mark with deionized water. The concentrations of heavy metals in the sample were determined by FAAS. The same process was also carried out with another set of $10 \mathrm{~mL}$ of water samples collected to which $2 \mathrm{~mL}$ of 8-hydroxyquinoline and $0.2 \mathrm{~mL}$ of $\mathrm{Cu}(\mathrm{II})$ solutions corresponding to $2 \mathrm{mg}$ of the ligand and $0.2 \mathrm{mg}$ of the carrier element, respectively, were added under the optimized conditions earlier established with the model solutions. The solution was subsequently centrifuged at $3500 \mathrm{rpm}$ for $20 \mathrm{~min}$ and the precipitate formed was dissolved in $1 \mathrm{~mL}$ nitric acid, and made up made up to the mark with distilled water in a $10 \mathrm{~mL}$ volumetric flask. The concentrations of $\mathrm{Cd}(\mathrm{II}), \mathrm{Co}(\mathrm{II}), \mathrm{Cr}(\mathrm{III}), \mathrm{Ni}(\mathrm{II})$ and $\mathrm{Pb}(\mathrm{II})$ were determined in the solution by FAAS. 
Fig. 1 Map of Lagos Lagoon showing sampling points

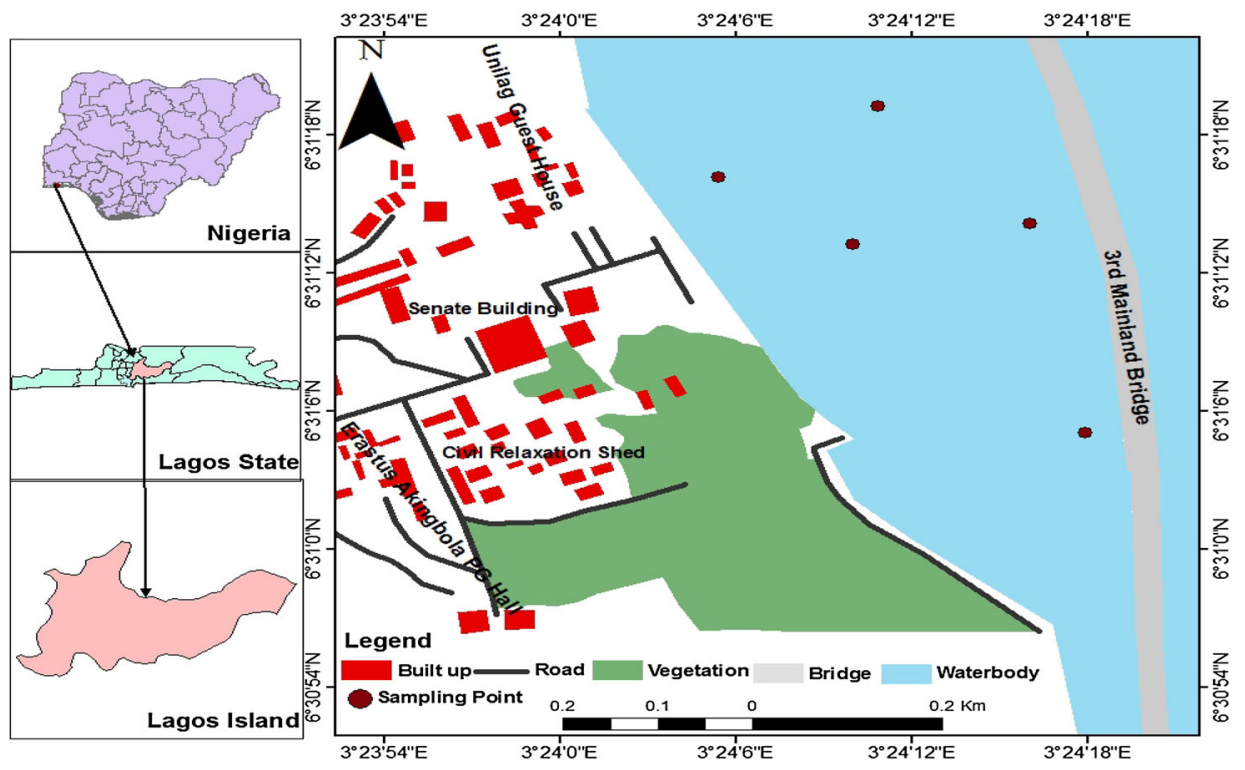

The metal pollution index (PI) was evaluated using the expression (2), where $C_{i(\max )}$ and $C_{i(\min )}$ are the maximum and minimum concentrations of each metal and $S_{i}$ is the metal concentration according to WHO water quality criteria.

$\mathrm{PI}=\frac{\sqrt{\left(\frac{C_{i}}{S_{i}}\right)^{2}+\left(\frac{C_{i}}{S_{i}}\right)^{2}}}{2}$

$1000 \mu \mathrm{g} / \mathrm{mL}$ copper(II) solution as a carrier element and $2 \mathrm{~mL}$ of 8 -HQ solution as a ligand, and $\mathrm{pH}$ of the solutions was adjusted to $\mathrm{pH}$ 9. The solutions were centrifuged and the precipitates formed were dissolved in $1 \mathrm{~mL}$ nitric acid. The solutions were made up to the mark in a $10 \mathrm{~mL}$ volumetric flask and the concentrations of metal ions were reanalyzed by FAAS. This process was replicated five times. The percent recovery of the metal ions was calculated using the expression (1).

\section{Results and discussions}

\section{Effect of pH on metal recovery in model solutions}

The influence of $\mathrm{pH}$ on the model solutions of $20 \mu \mathrm{g}$ of $\mathrm{Pb}(\mathrm{II}), \mathrm{Cr}(\mathrm{III}), \mathrm{Ni}(\mathrm{II}), \mathrm{Co}(\mathrm{II})$ and $\mathrm{Cd}(\mathrm{II})$ was investigated

Recovery $(\%)=\frac{(\text { Metal ion concentration after re }- \text { analysis }- \text { Metal ion concentration without spiking }) \times 100}{\text { Metal ion concentration without spiking }}$

\section{Analysis of certified reference sediment material}

A $0.1 \mathrm{~g}$ of the standard reference material for sediment, STSD-4 which was obtained from the Canadian Center for Mineral and Energy Technology (CANMET) was weighed and digested with $10 \mathrm{~mL}$ concentrated nitric acid at room temperature on a water bath for $2 \mathrm{~h}$. The digested sample was filtered into a $10 \mathrm{~mL}$ volumetric flask and made up to mark. The procedure in the certificate of the reference material requires nitric acid digestion to effect dissolution of the material and form soluble nitrate form of the metals in solution. The filtered sample was then placed into a centrifuge tube. The coprecipitation method was then carried out on the material. within the range of 3-10 (Fig. 2). The recoveries were minimal within the $\mathrm{pH}$ range of 3-7. However, the highest recoveries for the model solutions were within the $\mathrm{pH}$ range of $8-10$. The recovery values for the $\mathrm{pH}$ of 8-10 ranged from 60.0 to $98.0 \%$ (Fig. 2) for $\mathrm{Pb}(\mathrm{II}$ ), $\mathrm{Cr}(\mathrm{III}), \mathrm{Cd}(\mathrm{II}), \mathrm{Ni}(\mathrm{II})$ and $\mathrm{Co}(\mathrm{II})$. Therefore, optimum $\mathrm{pH}$ value of 9 was selected for subsequent work of the preconcentration of $\mathrm{Ni}(\mathrm{II}), \mathrm{Co}(\mathrm{II}), \mathrm{Cd}(\mathrm{II}), \mathrm{Cr}(\mathrm{III})$ and $\mathrm{Pb}$ (II) solutions. A preconcentration factor of 60 was reported when $\mathrm{Cd}(\mathrm{II}), \mathrm{Ni}(\mathrm{II})$ and $\mathrm{Pb}(\mathrm{II})$ from standard solutions were quantitatively coprecipitated using 8-hyroxyquinoline (8-HQ) as a chelating agent and lanthanum (III) as a carrier element (Feist and Mikula 
2014). The recoveries of all the metals ions were quantitative $(>70 \%)$ at the $\mathrm{pH}$ of 8 , with $2 \mathrm{mg}$ of lanthanum (III) and $2 \mathrm{~mL}$ of $5 \%$ 8-hydroxyquinoline. Using 8-HQ anchored magnetic chitosan, maximum removal of cobalt ion was obtained at $\mathrm{pH} \mathrm{8-9} \mathrm{similar} \mathrm{to}$ the optimum $\mathrm{pH}$ obtained in this study (Beyki et al. 2016).

Fig. 2 Effect of $\mathrm{pH}$ on the recovery of heavy metals in the model solutions
Fig. 3 Effect of Amount of $\mathrm{Cu}^{2+}$ as carrier element on heavy metal recovery

\section{Effect of $\mathrm{Cu}(\mathrm{II})$ as a carrier element on metal recovery in model solutions}

The effect of the amount of $\mathrm{Cu}$ (II) as carrier element on the model solutions was investigated within the range of 0-1.4 mg (Fig. 3). The percentage recoveries were in the range of $65.5-75.6 \%$ for the metals investigated when no
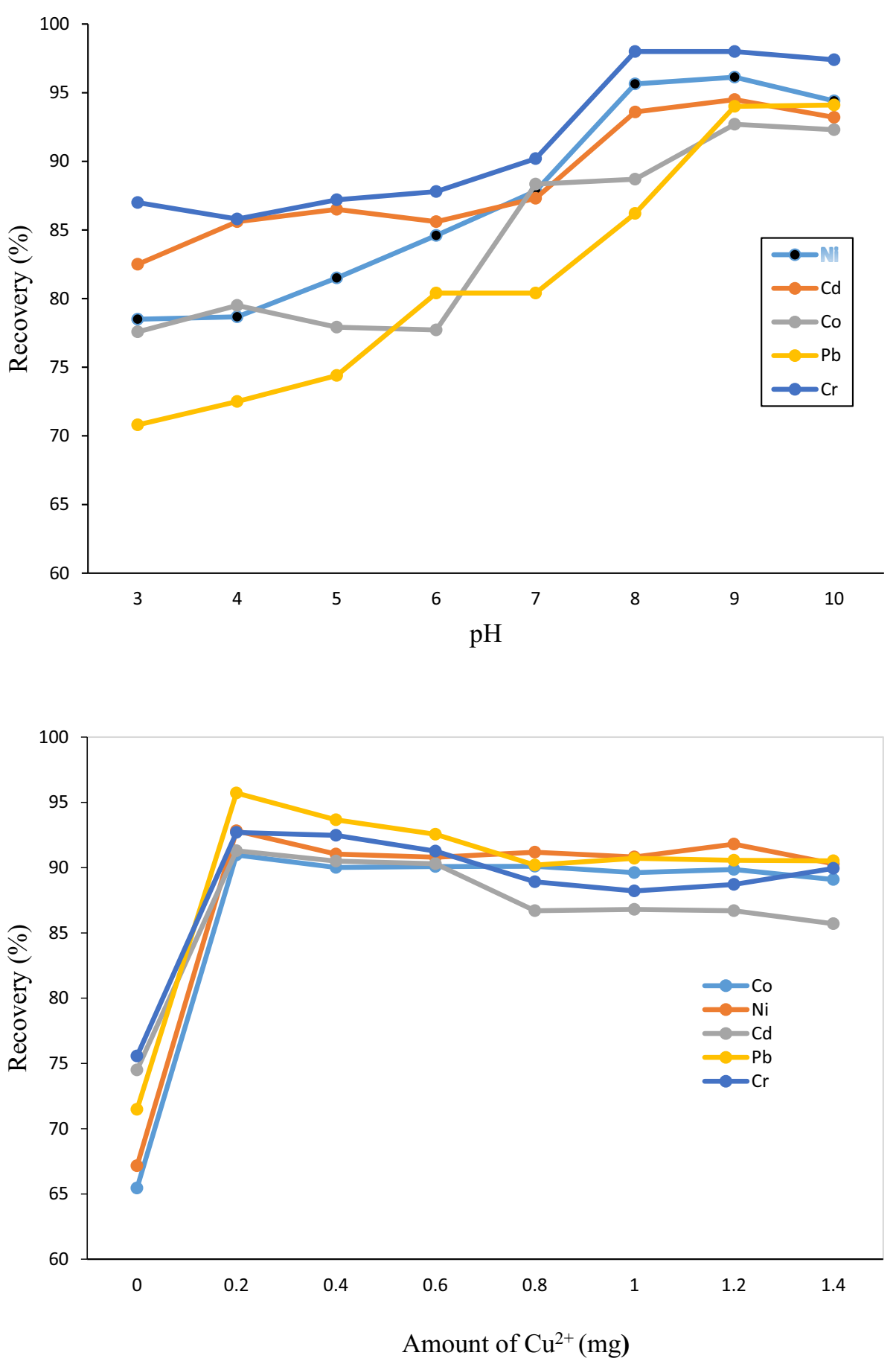
carrier element was used. In the presence of $\mathrm{Cu}(\mathrm{II})$ as a carrier element, the recoveries of the metal solutions increase quantitatively by the addition of $0.2-0.8 \mathrm{mg}$ of carrier element for $\mathrm{Co}$ and $\mathrm{Pb}, 0.2-0.6 \mathrm{mg}$ for $\mathrm{Cd}$ and $\mathrm{Cr}$. The recoveries decreased for these metals as more copper(II) solution was added beyond these levels. $\mathrm{Ni}$ and $\mathrm{Pb}$ were quantitatively recovered from the metal ion solutions by the addition of $0.2-1.4 \mathrm{mg}$ of $\mathrm{Cu}$ (II) solution as carrier element (Fig. 3). Therefore, for subsequent work, the optimum amount of $\mathrm{Cu}$ (II) solution used in the preconcentration and separation of metals from the model solutions was $0.2 \mathrm{mg}$. The results showed that preconcentration method yielded an optimum result with the use of $\mathrm{Cu}$ (II) as a carrier element. For all the metals, the percentage recoveries for the solutions that had no copper(II) yielded the lowest concentrations.

\section{Effect of 8-hydroxyquinoline on metal recovery in model solutions}

The effect of the amount of 8-hydroxyqunoline as a ligand on the model solutions were investigated within the range of $1.0-7.0 \mathrm{mg}$ (Fig. 4). This was carried out with a fixed amount $(0.2 \mathrm{mg})$ of carrier element and $25 \mathrm{~mL}$ each of the metal solutions. The 8-hydroxyquinoline first forms a solid phase with $\mathrm{Cu}(\mathrm{II})$ as carrier element before reacting with the metal ions in the solution ( $20 \mu \mathrm{g}$ each of the metal ions) which forms complex in the aqueous solution. The recoveries were quantitative $(>90.0 \%)$ at the addition of $2.0-7.0 \mathrm{mg}$ of 8-hydroxyquinoline into $\mathrm{Co}(\mathrm{II}), \mathrm{Cd}(\mathrm{II})$ $\mathrm{Cr}(\mathrm{III})$ and $\mathrm{Pb}$ (II) solutions. The percentage recoveries of $\mathrm{Ni}$ from the solution was in the range of $8.3-87.2 \%$. The optimum recoveries of the metals were obtained at $0.2 \mathrm{mg}$ of the 8-hydroxyquinoline (Fig. 4). Therefore, $2 \mathrm{mg}$ of 8-hydroxyquinoline was used for subsequent experiments. In a similar preconcentration experiment conducted with ionic liquid based microemulsion in which 8-hydroxyquinoline was used as a ligand, the recovery of $\mathrm{Cu}(\mathrm{II})$ was quantitative at $0.05 \mathrm{~mol} / \mathrm{L}$ of 8 -hydroxyquinoline. This quantity is equivalent to $72.5 \mathrm{mg}$ of 8-hydroxyquinoline, which is much higher than $2 \mathrm{mg}$ of 8-hydroxyquinoline obtained in this study (Arain et al. 2016).

\section{Effect of sample volume of metal recovery in model solutions}

The effect of volume of sample on the model solutions were investigated within the range of $10-250 \mathrm{~mL}$. The optimum recoveries of the metals were obtained at $10 \mathrm{~mL}$ of the sample volume within the range of $88.5-94.2 \%$ (Fig. 5). However, as the volume increased the recoveries reduced, indicating that at $250 \mathrm{~mL}$ the percentage recovery was very low giving a value between the range of $68.2-72.4 \%$ (Fig. 5). Therefore, $10 \mathrm{~mL}$ of the sample volume was used for subsequent works.

\section{Effect of interference ions on metal recovery}

One of the main problems of the atomic absorption spectrometry for determination of the heavy metal ions is the matrix interference. The effect of interference ions was, therefore, determined using the optimized conditions earlier identified. Some of these ions are alkali and alkali earth ions which are present in very high levels in environmental
Fig. 4 Effect of 8-hydroxylquinoline as ligand on heavy metal recovery

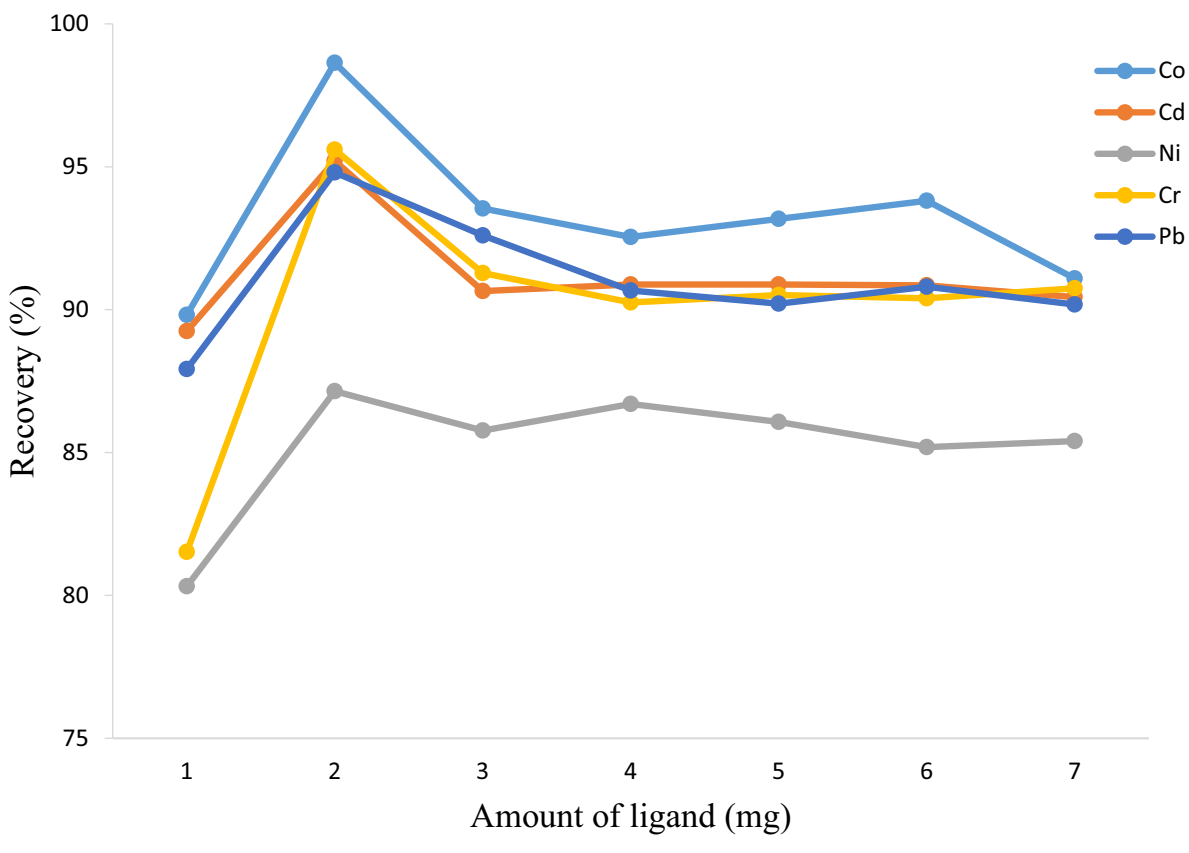


Fig. 5 Effect of sample volume on metal recovery in aqueous solutions

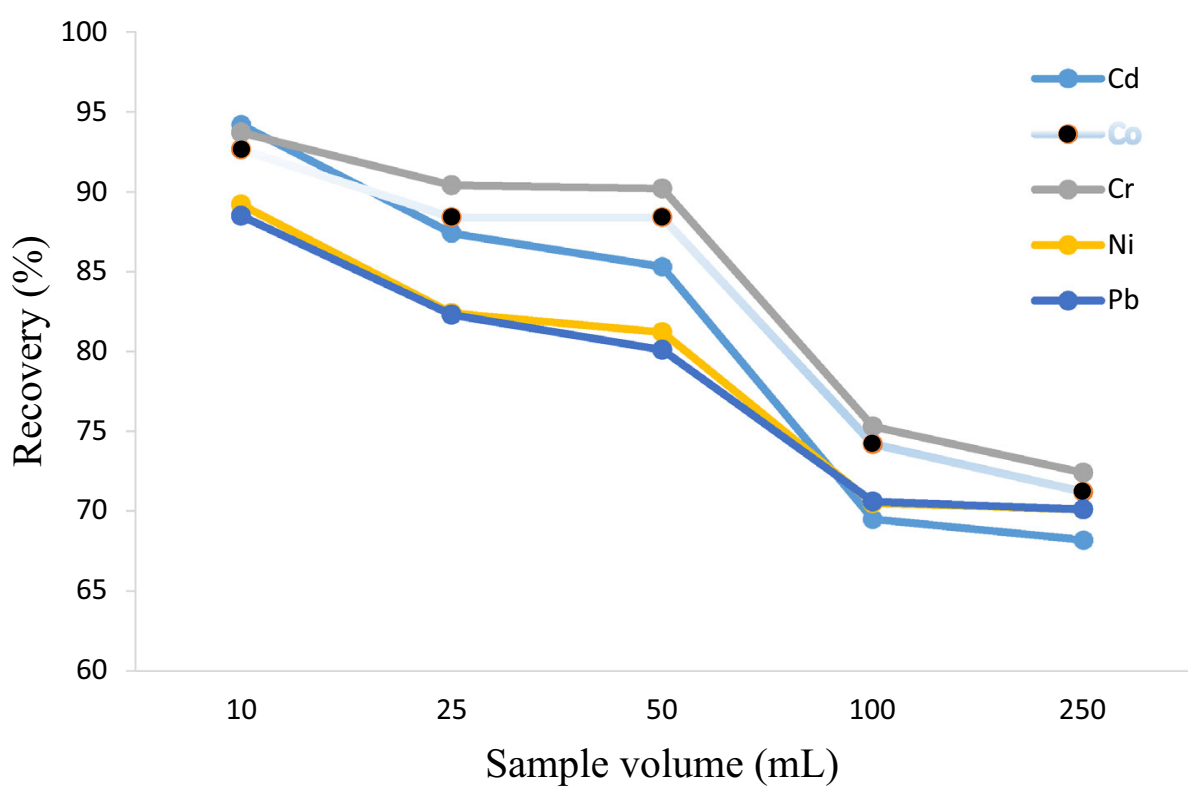

Table 1 Effect of interfering ion on co-precipitation procedure

\begin{tabular}{|c|c|c|c|c|c|c|c|c|}
\hline \multirow[t]{2}{*}{ Ions } & \multirow[t]{2}{*}{ Salt added } & \multirow{2}{*}{$\begin{array}{l}\text { Concentration ion } \\
\text { solution }(\mu \mathrm{g} / \mathrm{mL})\end{array}$} & \multirow{2}{*}{$\begin{array}{l}\text { Weight(g) of salt } \\
\text { dissolved/L }\end{array}$} & \multicolumn{5}{|c|}{ Recovery (\%) } \\
\hline & & & & $\mathrm{Ni}$ & Co & $\mathrm{Cd}$ & $\mathrm{Cr}$ & $\mathrm{Pb}$ \\
\hline $\mathrm{Na}^{+}$ & $\mathrm{NaCl}$ & 1000 & 2.543 & 84.1 & 97.5 & 85.0 & 94.7 & 74.8 \\
\hline $\mathrm{Cl}^{-}$ & $\mathrm{NaCl}$ & 1000 & 1.648 & 78.4 & 76.5 & 80.0 & 82.4 & 60.3 \\
\hline $\mathrm{K}^{+}$ & $\mathrm{KNO}_{3}$ & 1000 & 2.560 & 60.1 & 65.3 & 60.0 & 72.4 & 60.8 \\
\hline $\mathrm{Al}^{3+}$ & $\mathrm{Al}_{2}\left(\mathrm{SO}_{4}\right)_{3}$ & 1000 & 6.333 & 80.0 & 93.6 & 85.0 & 97.3 & 79.3 \\
\hline $\mathrm{Fe}^{2+}$ & $\mathrm{FeSO}_{4} .7 \mathrm{H}_{2} \mathrm{O}$ & 1000 & 4.978 & 95.2 & 97.7 & 70.0 & 87.6 & 97.1 \\
\hline $\mathrm{Zn}^{+}$ & $\mathrm{ZnSO}_{4}$ & 1000 & 2.468 & 66.0 & 84.5 & 80.0 & 85.3 & 82.8 \\
\hline
\end{tabular}

Table 2 Observed concentrations $(\mu \mathrm{g} / \mathrm{mL})$ of metals in standard reference materials with certified values

\begin{tabular}{|c|c|c|c|c|c|}
\hline \multirow[t]{2}{*}{ Metals } & \multicolumn{2}{|c|}{ Observed concentrations } & \multirow{2}{*}{$\begin{array}{l}\text { Certified } \\
\text { values }\end{array}$} & \multirow{2}{*}{$\begin{array}{l}* P \text { values } \\
(n=5)\end{array}$} & \multirow{2}{*}{$\begin{array}{l}\text { Significant difference } \\
\text { at } P=0.05(\mathrm{Yes} / \mathrm{No}) ?\end{array}$} \\
\hline & $\begin{array}{l}\text { Sediment without } \\
\mathrm{Cu}(\mathrm{II})-8 \mathrm{HQ}\end{array}$ & $\begin{array}{l}\text { Sediment with } \\
\mathrm{Cu}(\mathrm{II})-8 \mathrm{HQ}\end{array}$ & & & \\
\hline Co & $9.5 \pm 2.1$ & $14.0 \pm 0.1$ & 11 & 0.00025417 & Yes \\
\hline $\mathrm{Cr}$ & $32.0 \pm 0.1$ & $29.5 \pm 0.7$ & 30 & 0.00000004 & Yes \\
\hline $\mathrm{Ni}$ & $16.0 \pm 0.2$ & $25.5 \pm 1.6$ & 23 & 0.00000001 & Yes \\
\hline $\mathrm{Pb}$ & $9.0 \pm 0.1$ & $10.1 \pm 0.2$ & 13 & 0.00001415 & Yes \\
\hline
\end{tabular}

* $P$ value for the comparison of metal concentrations in sediment treated with and without $\mathrm{Cu}(\mathrm{II})-8 \mathrm{HQ}$

samples (Soylak 2004). Varying amount of the different foreign ions was taken with a fixed amount of metal solutions. The percentage recoveries of the metal ions were generally high showing that large amount of the foreign ions used had no significant effect on the determination of metal ions using co-precipitation method (Table 1).

The results of recoveries carried out on sediment reference material are given in Table 2. The results of replicate determinations of metals showed low levels of $\mathrm{Cr}(\mathrm{III})$ and $\mathrm{Pb}$ (II) but high levels of $\mathrm{Co}$ (II) and $\mathrm{Ni}$ (II) compared to the certified values. The metal ion concentrations in sediment treated with 8-HQ were about the certified values for the metals (Table 2). It was also observed that the concentrations of the metal ions in reference material treated with the 8-hydroxyquinoline ligand were higher than the concentrations obtained when the 
Table 3 Metal ion concentrations $(\mu \mathrm{g} / \mathrm{mL})$ in water sample before and after co-precipitation procedure application

\begin{tabular}{|c|c|c|c|c|}
\hline Metals & Water without $\mathrm{Cu}-8 \mathrm{HQ}$ & Water with $\mathrm{Cu}-8 \mathrm{HQ}$ & $P$ value & $\begin{array}{l}\text { Significance level at } \\
P=0.05(\text { Yes/No)? }\end{array}$ \\
\hline $\mathrm{Cd}$ & $<0.002$ & $<0.002$ & - & - \\
\hline $\mathrm{Ni}$ & $0.005 \pm 0.004$ & $0.03 \pm 0.01$ & 0.00486 & Yes \\
\hline $\mathrm{Pb}$ & $0.017 \pm 0.014$ & $0.04 \pm 0.02$ & 0.00498 & Yes \\
\hline $\mathrm{Cr}$ & $0.020 \pm 0.020$ & $0.05 \pm 0.02$ & 0.00505 & Yes \\
\hline Co & $0.009 \pm 0.007$ & $0.014 \pm 0.002$ & 0.00480 & Yes \\
\hline
\end{tabular}

Table 4 Comparison of this study with data from other studies on co-precipitation of heavy metal ions

\begin{tabular}{|c|c|c|c|c|c|c|c|c|}
\hline Analytes & Co-precipitation system & $\begin{array}{l}\text { Carrier } \\
\text { element }\end{array}$ & Application & $\begin{array}{l}\text { Dissolving } \\
\text { media }\end{array}$ & $\mathrm{pH}$ & $\mathrm{PF}$ & $\begin{array}{l}\text { Detection } \\
\text { technique }\end{array}$ & References \\
\hline Co, Mn & $\begin{array}{l}\text { Copper-8- } \\
\text { hydroxyquinoline }\end{array}$ & $\mathrm{Cu}$ & $\begin{array}{l}\text { Food sample and natural } \\
\text { water }\end{array}$ & $\begin{array}{l}0.5 \mathrm{~mL} \text { conc. } \\
\mathrm{HNO}_{3}\end{array}$ & 8 & 25 & FAAS & $\begin{array}{l}\text { Soylak et al. } \\
\text { (2007) }\end{array}$ \\
\hline $\begin{array}{l}\mathrm{Cu}, \mathrm{Cd}, \mathrm{Co}, \mathrm{Ni}, \\
\mathrm{Fe}, \mathrm{Pb}\end{array}$ & Thulium hydroxide & $\mathrm{Tm}$ & Food and soil samples & $\begin{array}{l}0.5 \mathrm{~mL} \text { conc. } \\
\mathrm{HNO}_{3}\end{array}$ & 11 & 120 & FAAS & $\begin{array}{l}\text { Soylak and } \\
\text { Aydin (2011) }\end{array}$ \\
\hline $\mathrm{Ni}, \mathrm{Cd}, \mathrm{Pb}$ & Copper hydroxide & $\mathrm{Cu}$ & Water sample & $\begin{array}{l}0.5 \mathrm{~mL} \text { conc. } \\
\mathrm{HNO}_{3}\end{array}$ & 9 & 100 & FAAS & $\begin{array}{l}\text { Soylak et al. } \\
\text { (2008) }\end{array}$ \\
\hline $\begin{array}{l}\mathrm{Cd}, \mathrm{Cu}, \mathrm{Ni}, \mathrm{Pb}, \\
\quad \mathrm{Zn}\end{array}$ & $\begin{array}{l}\text { Lanthan-8- } \\
\text { hydroxyquinoline }\end{array}$ & $\mathrm{La}$ & Plant materials & $\begin{array}{c}5 \mathrm{~mL}, 2 \mathrm{~mol} / \mathrm{L} \\
\mathrm{HNO}_{3}\end{array}$ & 8 & 60 & FAAS & $\begin{array}{l}\text { Feist and Mikula } \\
\text { (2014) }\end{array}$ \\
\hline $\begin{array}{l}\mathrm{Pb}, \mathrm{Cd}, \mathrm{Cr}, \mathrm{Ni}, \\
\quad \mathrm{Mn}\end{array}$ & Dibenzyldithiocarbamate & $\mathrm{Cu}$ & Water samples & $\begin{array}{l}0.5 \mathrm{~mL} \text { conc. } \\
\mathrm{HNO}_{3}\end{array}$ & 9 & 50 & $\begin{array}{l}\text { FAAS ICP- } \\
\text { OES }\end{array}$ & $\begin{array}{l}\text { Tuzen and } \\
\text { Soylak (2009) }\end{array}$ \\
\hline $\mathrm{Al}$ & $\begin{array}{l}\text { Cobalt-8- } \\
\text { hydroxylquinoline }\end{array}$ & Co & $\begin{array}{l}\text { Water samples and } \\
\text { dialysis solutions }\end{array}$ & $\begin{array}{l}0.5 \mathrm{~mL} \text { conc. } \\
\mathrm{HNO}_{3}\end{array}$ & 8 & 50 & FAAS & $\begin{array}{l}\text { Bulut et al. } \\
\text { (2010) }\end{array}$ \\
\hline $\begin{array}{l}\mathrm{Co}, \mathrm{Cd}, \mathrm{Pb}, \mathrm{Ni} \text {, } \\
\mathrm{Cr}\end{array}$ & $\begin{array}{l}\text { Copper-8- } \\
\text { hydroxyquinoline }\end{array}$ & $\mathrm{Cu}$ & Water sample & $\begin{array}{l}1.0 \mathrm{~mL} \text { conc. } \\
\mathrm{HNO}_{3}\end{array}$ & 9 & 25 & FAAS & This study \\
\hline
\end{tabular}

ligand was not used. This is an indication that the preconcentration of the metals from the standard sediment sample can be enhanced by the ligand.

\section{Application of co-precipitation procedure to real samples and comparison with other studies}

Table 3 shows that the metal concentrations obtained when co-precipitation procedure was applied for metal ions determination in water sample via FAAS were well above the corresponding concentrations when co-precipitation procedure was not followed. A comparison of the proposed co-precipitation procedure in this study with the other reported preconcentration methods for cadmium, nickel, chromium, lead and cobalt ions extraction from water samples are shown in Table 4 (Bulut et al. 2010; Feist and Mikula 2014; Soylak and Aydin 2011; Soylak et al. 2007, 2008; Tuzen and Soylak 2009). Using similar precipitate dissolving media $\left(\mathrm{HNO}_{3}\right)$, the coprecipitation procedure for metal ions with 8-hydoxyquinoline as a ligand yielded low precipitation factor (PF) compared to those reported in the literatures for which other ligands were used (Table 4).
The variables used for the quantification of metal pollution index are shown in Table 5. Considering the magnitude of PI, the quality of any surface water can be classified as being slightly affected, moderately affected, strongly affected and seriously affected with heavy metals if PI value is between $1-2,2-3,3-5$ and $>5$ (Goher et al. 2014). Using the metal concentrations of water sample treated with 8-hydoxyquinoline, pollution load of 3.74 was obtained indicating that Lagos lagoon water was strongly impacted with heavy metals. Metal pollution was equally noticed in Manzala, Burullus and Edku lagoons in Egypt. The contamination of the three lagoons occurred as a result of heavily polluted drainage wastewaters from urban agricultural and industrial sources. The concentrations of $\mathrm{Cd}(\mathrm{II})$ and $\mathrm{Pb}$ (II) as shown in Table 6 were reported to be higher such that aquatic organism tend to accumulate them in the tissue (El-Shazly et al. 2016). The high concentrations of $\mathrm{Ni}$ (II) and $\mathrm{Pb}$ (II) in Tampamachoco lagoon in Mexico was attributed to fuel oil discharge water rich in heavy metals that flowed from a thermal power plant into the lagoon water. The analytical procedure adopted for the determination of $\mathrm{Ni}(\mathrm{II})$ and $\mathrm{Pb}$ (II) in Tampamachoco lagoon water sample was similar to the procedure 
Table 5 Quantification of pollution load index from metal concentrations $(\mu \mathrm{g} / \mathrm{mL})$ and WHO standard values $(\mathrm{Si})$

\begin{tabular}{lcclll}
\hline Metal ion & $\mathrm{Ci}(\min )$ & $\mathrm{Ci}(\max )$ & $\mathrm{Si}$ & {$\left[(\mathrm{Ci} / \mathrm{Si})_{\min }\right]^{2}$} & {$\left[(\mathrm{Ci} / \mathrm{Si})_{\max }\right]^{2}$} \\
\hline $\mathrm{Cd}(\mathrm{II})$ & $<0.002$ & $<0.002$ & 0.003 & - & - \\
$\mathrm{Ni}(\mathrm{II})$ & 0.005 & 0.061 & 0.07 & 0.020 & 0.759 \\
$\mathrm{~Pb}(\mathrm{II})$ & 0.011 & 0.072 & 0.01 & 1.210 & 51.84 \\
$\mathrm{Cr}(\mathrm{II})$ & 0.024 & 0.068 & 0.05 & 0.230 & 1.850 \\
$\mathrm{Co}(\mathrm{II})$ & 0.013 & 0.028 & - & - & - \\
\hline
\end{tabular}

Table 6 Comparison of metal concentrations $(\mathrm{mg} / \mathrm{L})$ in the study with previous studies in other countries

\begin{tabular}{|c|c|c|c|c|c|c|}
\hline Surface water & $\mathrm{Cd}(\mathrm{II})$ & $\mathrm{Co}(\mathrm{II})$ & $\mathrm{Cr}(\mathrm{III})$ & $\mathrm{Ni}(\mathrm{II})$ & $\mathrm{Pb}(\mathrm{II})$ & References \\
\hline Lagos lagoon, Nigeria & $<0.002$ & $0.014 \pm 0.001$ & $0.05 \pm 0.01$ & $0.03 \pm 0.02$ & $0.04 \pm 0.03$ & This study \\
\hline Manzala lagoon, Egypt & $0.003 \pm 0.002$ & & & & $0.027 \pm 0.0002$ & El-Shazly et al. (2016) \\
\hline Burullus lagoon, Egypt & $0.0020 \pm 0.0003$ & & & & $0.0340 \pm 0.0004$ & El-Shazly et al. (2016) \\
\hline Edku lagoon, Egypt & $0.0040 \pm 0.0001$ & & & & $0.036 \pm 0.002$ & El-Shazly et al. (2016) \\
\hline $\begin{array}{l}\text { Tampamachoco lagoon, } \\
\text { Mexico }\end{array}$ & & & & 0.0297 & 0.0043 & Ruiz et al. (2016) \\
\hline Sunderban reserve, India & $0.003-0.062$ & & & $0.53-1.05$ & $0.08-0.17$ & Chowdhury and Maiti (2016) \\
\hline Dhaka lagoon, Bangladesh & 0.13 & 0.41 & 5.27 & 0.33 & 0.81 & Bhuiyan et al. (2011) \\
\hline
\end{tabular}

implemented in this study. The only exception was the use of Chelex-100 for preconcentration procedure. The metal concentrations were 0.0297 and $0.00431 \mu \mathrm{g} / \mathrm{mL}$ for $\mathrm{Ni}$ and $\mathrm{Pb}$, respectively (Ruiz et al. 2016). With the increasing negative impact of metal pollution in Mexico lagoon water due to petroleum activities, certain heavy metals such as $\mathrm{Cd}(\mathrm{II}), \mathrm{Cr}$ (III), $\mathrm{Ni}$ (II) and $\mathrm{Pb}$ (II) were bio-accumulated in the aquatic organisms found in a tropical estuarine lagoon in South East Mexico (Mendoza-Carranza et al. 2016).

Lead pollution is prevalent in lagoons where the fossil fuel-operated boats are commonly plying for transport. High impact of lead pollution in the river water of Sunderban reserve in India was attributed to fossil-operated boats that shuttle the river (Chowdhury and Maiti 2016). This anthropogenic activity could also be responsible for high lead concentration of $0.04 \pm 0.03 \mu \mathrm{g} / \mathrm{mL}$ obtained in Lagos lagoon water (Table 6). The heavy metal pollution load of tannery effluent-impacted lagoon in Southwestern Dhaka, Bangladesh has been reported (Bhuiyan et al. 2011). The mean concentration of $\operatorname{Cr}(5.27 \mu \mathrm{g} / \mathrm{mL})$, $\mathrm{Pb}(0.81 \mu \mathrm{g} / \mathrm{mL}), \mathrm{Cd}(0.13 \mu \mathrm{g} / \mathrm{mL})$ in the lagoon water were observed to be high and could have public health and potential environmental implications.

\section{Conclusions}

The proposed procedure centered on co-precipitation of $\mathrm{Cd}, \mathrm{Co}, \mathrm{Ni}, \mathrm{Cr}$ and $\mathrm{Pb}$ by 8-hydroxyquinoline precipitating reagent with $\mathrm{Cu}^{2+}$ as carrier element. The procedure is simple, accurate, efficient and free of any interfering ions compared to other methods that are used for determining analyte metal ions in any given water and other environmental samples. The quantitative recoveries of analyte ions were high $(>85 \%)$ at the optimal experimental conditions. The separation of metal ions from the matrix of water sample was enhanced when the sample was treated with precipitating ligand. This procedure can be applied to various kinds of environmental samples. The reason is that FAAS provides an effective, cheap, rapid and reliable technique for the determination of analyte ions in environmental samples.

Open Access This article is distributed under the terms of the Creative Commons Attribution 4.0 International License (http:// creativecommons.org/licenses/by/4.0/), which permits unrestricted use, distribution, and reproduction in any medium, provided you give appropriate credit to the original author(s) and the source, provide a link to the Creative Commons license, and indicate if changes were made.

\section{References}

Abdel-Satar A, Geneid Y (2009) Evaluation of heavy metal status in ecosystem of lake Manzalah, Egypt. Global J Environ Res 3:194-204

Ajao E (1990) The influence of domestic and industrial effluents on populations of sessile and benthic organisms in Lagos Lagoon. Ph.D. Thesis, University of Ibadan, Nigeria

Åkesson A, Bjellerup P, Lundh T, Lidfeldt J, Nerbrand C, Samsioe G, Skerfving S, Vahter M (2006) Cadmium-induced effects on bone 
in a population-based study of women. Environ Health Perspect 114(6):830-834

APHA-AWWA-WPCF (1981) Standard methods for the examination of water and wastewater APHA American Public Health Association

Arain SA, Kazi TG, Afridi HI, Arain MS, Panhwar AH, Khan N, Baig JA, Shah F (2016) A new dispersive liquid-liquid microextraction using ionic liquid based microemulsion coupled with cloud point extraction for determination of copper in serum and water samples. Ecotoxicol Environ Saf 126:186-192

Awoyemi OM, Achudume AC, Okoya AA (2014) The physicochemical quality of groundwater in relation to surface water pollution in Majidun area of Ikorodu, Lagos State, Nigeria. Am J Water Resour 2:126-133

Beyki MH, Shemirani F, Shirkhodaie M (2016) Aqueous Co (II) adsorption using 8-hydroxyquinoline anchored $\gamma-\mathrm{Fe}_{2} \mathrm{O}_{3} @$ chitosan with Co (II) as imprinted ions. Int J Biol Macromol 87:375-384

Bhuiyan MAH, Suruvi NI, Dampare SB, Islam M, Quraishi SB, Ganyaglo S, Suzuki S (2011) Investigation of the possible sources of heavy metal contamination in lagoon and canal water in the tannery industrial area in Dhaka, Bangladesh. Environ Monit Assess 175:633-649

Bulut VN, Arslan D, Ozdes D, Soylak M, Tufekci M (2010) Preconcentration, separation and spectrophotometric determination of aluminium (III) in water samples and dialysis concentrates at trace levels with 8-hydroxyquinoline-cobalt (II) coprecipitation system. J Hazard Mater 182:331-336

Çelik Z, Gülfen M, Aydın AO (2010) Synthesis of a novel dithiooxamide-formaldehyde resin and its application to the adsorption and separation of silver ions. J Hazard Mater 174:556-562

Chen H, Jin J, Wang Y (1997) Flow injection on-line coprecipitationpreconcentration system using copper (II) diethyldithiocarbamate as carrier for flame atomic absorption spectrometric determination of cadmium, lead and nickel in environmental samples. Anal Chim Acta 353:181-188

Chowdhury A, Maiti SK (2016) Identifying the source and accessing the spatial variations, contamination status, conservation threats of heavy metal pollution in the river waters of Sunderban biosphere reserve, India. J Coast Conserv 20:257-269

Depecker G, Branger C, Margaillan A, Pigot T, Blanc S, RobertPeillard F, Coulomb B, Boudenne JL (2009) Synthesis and applications of XAD-4-DAN chelate resin for the separation and determination of Se (IV). React Funct Polym 69:877-883

Duan T, Kang J, Chen H, Zeng X (2003) Determination of ultra-trace concentrations of elements in high purity tellurium by inductively coupled plasma mass spectrometry after $\mathrm{Fe}(\mathrm{OH})_{3}$ coprecipitation. Spectrochim Acta Part B 58:1679-1685

Elci L, Soylak M, Özcan B (2003) Coprecipitation of Cu (II), Ni (II), $\mathrm{Fe}(\mathrm{III}), \mathrm{Cd}$ (II), $\mathrm{Pb}$ (II), and $\mathrm{Co}$ (II) in wastewater, sediment, and metallic zinc samples with HMDTC-HMA for flame atomic absorption spectrometric determination. Anal Lett 36:987-999

El-Shazly MM, Omar WA, Edmardash YA, Ibrahim MS, Elzayat EI, El-Sebeay II, Abdel Rahman KM, Soliman MM (2016) Area reduction and trace element pollution in Nile Delta wetland ecosystems. Afr J Ecol. doi:10.1111/aje.12264

Feist B, Mikula B (2014) Preconcentration of some metal ions with lanthanum-8-hydroxyquinoline co-precipitation system. Food Chem 147:225-229

Goher ME, Hassan AM, Abdel-Moniem IA, Fahmy AH, El-sayed SM (2014) Evaluation of surface water quality and heavy metal indices of Ismailia Canal, Nile River, Egypt. Egypt J Aquat Res 40:225-233

Harvey P, Handley H, Taylor M (2015) Identification of the sources of metal (lead) contamination in drinking waters in north-eastern
Tasmania using lead isotopic compositions. Environ Sci Pollut Res 22:12276-12288

Hill M, Webb J (1958) The ecology of Lagos Lagoon. II. The topography and physical features of Lagos Harbour and Lagos Lagoon. Philos Trans R Soc Lond B Biol Sci 241:319-333

Marahel F, Ghaedi M, Montazerozohori M, Biyareh MN, Kokhdan SN, Soylak M (2011) Solid-phase extraction and determination of trace amount of some metal ions on Duolite XAD 761 modified with a new Schiff base as chelating agent in some food samples. Food Chem Toxicol 49:208-214

Marchand C, Lallier-Verges E, Baltzer F, Albéric P, Cossa D, Baillif P (2006) Heavy metals distribution in mangrove sediments along the mobile coastline of French Guiana. Mar Chem 98:1-17

Mendoza-Carranza M, Sepúlveda-Lozada A, Dias-Ferreira C, Geissen V (2016) Distribution and bioconcentration of heavy metals in a tropical aquatic food web: a case study of a tropical estuarine lagoon in SE Mexico. Environ Pollut 210:155-165

Okusipe OM (2003) Lagos Lagoon coastal profile: Information database for planning theory. Department of Urban and Regional Planning, University of Lagos, Lagos

Otero-Romaní J, Moreda-Piñeiro A, Bermejo-Barrera P, MartinEsteban A (2009) Inductively coupled plasma-optical emission spectrometry/mass spectrometry for the determination of $\mathrm{Cu}, \mathrm{Ni}$, $\mathrm{Pb}$ and $\mathrm{Zn}$ in seawater after ionic imprinted polymer based solid phase extraction. Talanta 79:723-729

Pekey H (2006) Heavy metal pollution assessment in sediments of the Izmit Bay, Turkey. Environ Monit Assess 123:219-231

Rainey MP, Tyler A, Gilvear D, Bryant RG, McDonald P (2003) Mapping intertidal estuarine sediment grain size distributions through airborne remote sensing. Remote Sens Environ $86: 480-490$

Ruiz EG, Hoz LR, Edwards AC (2016) Dissolved copper, nickel and lead in Tampamachoco Lagoon and Tuxpan River Estuary in the SW Gulf of Mexico. Bull Environ Contam Toxicol 97:490-496

Soylak M (2004) Solid phase extraction of $\mathrm{Cu}$ (II), $\mathrm{Pb}(\mathrm{II}), \mathrm{Fe}(\mathrm{III}), \mathrm{Co}$ (II), and $\mathrm{Cr}$ (III) on chelex-100 column prior to their flame atomic absorption spectrometric determinations. Anal Lett 37:1203-1217

Soylak M, Aydin A (2011) Determination of some heavy metals in food and environmental samples by flame atomic absorption spectrometry after coprecipitation. Food Chem Toxicol 49:1242-1248

Soylak M, Saracoglu S, Divrikli U, Elci L (2005) Coprecipitation of heavy metals with erbium hydroxide for their flame atomic absorption spectrometric determinations in environmental samples. Talanta 66:1098-1102

Soylak M, Kaya B, Tuzen M (2007) Copper (II)-8-hydroxquinoline coprecipitation system for preconcentration and separation of cobalt (II) and manganese (II) in real samples. J Hazard Mater 147:832-837

Soylak M, Kars A, Narin I (2008) Coprecipitation of $\mathrm{Ni}^{2+}, \mathrm{Cd}^{2+}$ and $\mathrm{Pb}^{2+}$ for preconcentration in environmental samples prior to flame atomic absorption spectrometric determinations. J Hazard Mater 159:435-439

Tchounwou PB, Yedjou CG, Patlolla AK, Sutton DJ (2012) Heavy metal toxicity and the environment, molecular, clinical and environmental toxicology. Springer, New York, pp 133-164

Tokman N, Akman S, Ozeroglu C (2004) Determination of lead, copper and manganese by graphite furnace atomic absorption spectrometry after separation/concentration using a water-soluble polymer. Talanta 63:699-703

Tuzen M, Soylak M (2009) Multi-element coprecipitation for separation and enrichment of heavy metal ions for their flame atomic absorption spectrometric determinations. J Hazard Mater 162:724-729

Uluozlu OD, Tuzen M, Mendil D, Soylak M (2010) Coprecipitation of trace elements with $\mathrm{Ni}^{2+} / 2-\mathrm{Nitroso}$-1-naphthol-4-sulfonic 
acid and their determination by flame atomic absorption spectrometry. J Hazard Mater 176:1032-1037

Vircavs M, Rone V, Vircava D (1994) Coprecipitation study of $\mathrm{As}(\mathrm{III}), \mathrm{Cu}(\mathrm{II})$ and $\mathrm{Cd}(\mathrm{II})$ from aqueous solution using 5-bromo and 2-methylthioquinoline-8-thiol. Fresenius' J Anal Chem 350:650-651

Yang L, Hu B, Jiang Z, Pan H (2004) On-line separation and preconcentration of trace metals in biological samples using a microcolumn loaded with PAN-modified nanometer-sized titanium dioxide, and their determination by ICP-AES. Microchim Acta 144:227-231

Yıldız E, Saçmacı Ş, Kartal Ş, Saçmacı M (2016) A new chelating reagent and application for coprecipitation of some metals in food samples by FAAS. Food Chem 194:143-148

Zhang L, Chang X, Li Z, He Q (2010) Selective solid-phase extraction using oxidized activated carbon modified with triethylenetetramine for preconcentration of metal ions. J Mol Struct 964:58-62 